\title{
Studies on the nutrition of marine flatfish. The thiamin requirement of turbot (Scophthalmus maximus)
}

\author{
By C. B. COWEY, J. W. ADRON and D. KNOX \\ Institute of Marine Biochemistry, St Fittick's Road, Aberdeen ABI ${ }_{3} R A$ \\ AND G. T. BALL \\ Fisheries Laboratory, Breakwater Road, Port Erin, Isle of Man \\ (Received I November 1974-Accepted 3 March 1975)
}

\begin{abstract}
1. Seven groups of young turbot (Scophthalmus maximus) were given diets containing graded levels of thiamin $(0 \cdot 19-50 \mathrm{mg} / \mathrm{kg})$ for 16 weeks and their growth rate was measured during this period.

2. Good growth was obtained on all these treatments except in the group given the lowest dietary thiamin level $(0.19 \mathrm{mg} / \mathrm{kg})$. These fish grew normally until the 12 th week but thereafter their weight did not increase.

3. Measurements of erythrocyte transketolase (sedoheptulose-7-phosphate: D-glyceraldehyde-3-phosphate glycolaldehydetransferase; $E C \quad 2.2 . I . I)$ activity at the end of the experiment and of percentage stimulation of erythrocyte transketolase by thiamin pyrophosphate indicated that the apoenzyme was saturated with coenzyme at a dietary thiamin level of 2.6 $\mathrm{mg} / \mathrm{kg}$, but not at $\mathrm{I} \cdot \mathrm{I} \mathrm{mg} / \mathrm{kg}$.

4. An 8th group of turbot given the thiamin antagonist pyrithiamin ( $40 \mathrm{mg} / \mathrm{kg} \mathrm{diet}$ ) grew normally for 6 weeks. Thereafter mortalities began to occur and all fish died by the roth week. No clear-cut signs of thiamin deficiency were observed.

5. The dietary thiamin requirement of turbot is much lower than published requirements of freshwater fish other than carp (Cyprinus carpio) and appears to be between 0.6 and 2.6 $\mathrm{mg} / \mathrm{kg}$ diet.
\end{abstract}

The requirement of several species of freshwater fish for a dietary source of thiamin has been established by giving them diets containing graded levels of thiamin for prolonged periods ( $16-18$ weeks). The growth-response curves obtained by application of this procedure to various species of trout and to Chinook salmon (Oncorhynchus tsc hawytscha) indicate that they require $10-15 \mathrm{mg}$ thiamin $/ \mathrm{kg}$ dry diet for maximum weight gain (Halver, I972), and the recommended level for trout, salmon and channel catfish (Ictalurus punctatus) diets is given as Io $\mathrm{mg}$ thiamin $/ \mathrm{kg}$ diet ((US) National Research Council, 1973). Deficiency signs begin to appear after fish have been given a thiamin-deficient diet for about 8-1o weeks. These signs include poor growth, poor appetite, and nervous disorders such as instability in the water and loss of equilibrium. A qualitative requirement for thiamin has also been shown in eels (Anguilla japonica) (Hashimoto, Arai \& Nose, 1970), which exhibit a flexion or winding of the trunk in the thiamin-deficient state.

The reported requirements of trout and Chinook salmon for thiamin are higher than those of omnivorous mammals. This is surprising, because the vitamin serves as a coenzyme in carbohydrate metabolism, and the fish are carnivorous and metabolize carbohydrate slowly. The requirement of carp (Cyprinus carpio) for thiamin is much more in line with expectation and appears to be met by dietary thiamin levels of 
$0.5 \mathrm{mg} / \mathrm{kg}$ dry diet, i.e. much lower than those reported for other freshwater fish (Aoe, Masuda, Mimura, Saito, Komo \& Kitamura, 1969).

Little information is available on the thiamin requirement of marine fish, although yellowtail (Seriola quinqueradiata) are reported to require the vitamin (Halver, 1972). To study further the thiamin requirement of marine flatfish, seven groups of turbot (Scophthalmus maximus) were given diets containing graded levels of thiamin $(0 \cdot 19-50 \mathrm{mg} / \mathrm{kg}$ dry diet) for 16 weeks. A further group of turbot were given a diet containing $40 \mathrm{mg}$ pyrithiamin (a thiamin antagonist) $/ \mathrm{kg}$ dry diet.

EXPERIMENTAL

Diets were prepared at the Institute of Marine Biochemistry, as described previously (Cowey, Pope, Adron \& Blair, r972) and made into moist pellets using an Alexanderwerk pelleting machine (Orthos (Engineering) Ltd, Market Harborough, Leicestershire). They were stored at $-15^{\circ}$ before transportation in solid carbon dioxide to Port Erin, Isle of Man, where the experiment was done. The diets were kept at $-15^{\circ}$ until used.

The composition of the basal diet (diet $\mathrm{r}$ ) is shown in Table $\mathbf{r}$. After pelleting, this diet contained $0.19 \mathrm{mg}$ thiamin $/ \mathrm{kg}$ as measured by microbiological assay (Sarett \& Cheldelin, 1944). Additional diets were made by adding graded levels of thiamin hydrochloride (Sigma Chemical Co. Ltd, London) to the basal diet. The thiamin contents of these diets were also checked, after pelleting, by microbiological assay and the measured thiamin levels are shown in Table 2. At the end of the experiment thiamin levels in diets $I-7$ were again measured; the values obtained were unchanged from those shown in Table 2. Diet 8 was the basal diet to which a thiamin antagonist, pyrithiamin (Sigma Chemical Co. Ltd), had been added at a level of $40 \mathrm{mg} / \mathrm{kg}$.

Turbot were reared from the egg at Port Erin as described by Jones (1973). For some time before metamorphosis they had been given diets composed mainly of minced trash fish. Before the start of the experiment turbot were marked by subdermal injection of differently coloured latex dyes on the ventral surface so that they were individually identifiable. Fish were then distributed between eight black Polythene tanks $(\mathrm{r} \cdot 20 \times 0.60 \times 0.03 \mathrm{~m}$ deep), about fifteen fish/tank, and weaned onto the artificial pelleted diet (diet 7) for 6 weeks. Most of the turbot readily accepted the artificial food and those that did not were discarded.

After weaning, the fish were re-allocated between the eight tanks. The fish were first divided into two groups on a weight basis; one group contained fish weighing from 10.0 to $14.9 \mathrm{~g}$, the other group contained fish weighing from $15^{\circ} \circ$ to $20.0 \mathrm{~g}$. Ten fish were then placed in each experimental tank, taking five fish at random from the lower weight range and five fish at random from the upper weight range. The total biomass in each of the eight tanks was reasonably similar (Table 3 ) as was the size distribution.

The fish were fed at 08.30 and $\mathrm{r} 6.30$ hours each day. For each treatment a quantity of moist pellets (corresponding in dry weight to $30 \mathrm{~g} / \mathrm{kg}$ total biomass of fish in the tank) was weighed daily and about fifteen to twenty pellets were dropped into the appropriate tank. These were normally eaten rapidly, and then more pellets were 
Table I Composition $(\mathrm{g} / \mathrm{kg})$ of the basal diet given to turbot

(Scophthalmus maximus)

$\begin{array}{lr}\text { Fish-protein concentrate* } & 500 \\ \text { Casein, vitamin-free } & 100 \\ \text { Dextrin } & 50 \\ \text { Glucose } & 200 \\ \text { Cod-liver oil } & 20 \\ \text { Herring oil } & 30 \\ \text { Mineral premix } † & 5 \\ \text { Vitamin premix } \downarrow & 28 \\ \text { Methionine } & 10 \\ \text { Arginine } & 7 \\ \text { Cellofas } & 50\end{array}$

* Protanimal; Astra Chemicals Ltd, Watford, Herts.

† Supplied (mg/kg dry diet): $\mathrm{Ca}\left(\mathrm{H}_{2} \mathrm{PO}_{4}\right)_{2} . \mathrm{H}_{2} \mathrm{O} 400, \mathrm{CaCO}_{3}$ Iooo, ferric citrate (hydrated) roo, $\mathrm{MgSO}_{4} \cdot 7 \mathrm{H}_{2} \mathrm{O} 400, \mathrm{~K}_{2} \mathrm{HPO}_{4} 700, \mathrm{Na}_{2} \mathrm{HPO}_{4} \cdot \mathrm{H}_{2} \mathrm{O} 250, \mathrm{AlCl}_{3} \cdot 6 \mathrm{H}_{2} \mathrm{O} 20, \mathrm{ZnCl}_{2} 60, \mathrm{CuSO}_{4} \cdot{ }_{5} \mathrm{H}_{2} \mathrm{O} 30$, $\mathrm{MnSO}_{4} \cdot 4 \mathrm{H}_{2} \mathrm{O} 20, \mathrm{KI} 2 \mathrm{O}, \mathrm{CoCl}_{2} \cdot 6 \mathrm{H}_{2} \mathrm{O} 30$.

$\ddagger$ Supplied (/kg dry diet): riboflavin $200 \mathrm{mg}$, pyridoxine hydrochloride $40 \mathrm{mg}$, nicotinic acid 800 $\mathrm{mg}$, calcium pantothenate $28 \mathrm{omg}$, myo-inositol $4 \mathrm{~g}$, biotin $6 \mathrm{mg}$, pteroylmonoglutamic acid $15 \mathrm{mg}$, $p$-aminobenzoic acid $400 \mathrm{mg}$, choline chloride $8 \mathrm{~g}$, ascorbic acid $2 \mathrm{~g}$, DL- $\alpha$-tocopheryl acetate $400 \mathrm{mg}$, menaphthone $40 \mathrm{mg}$, cyanocobalamin $90 \mu \mathrm{g}$.

$\S$ ICI Ltd, Ardrossan, Ayrshire.

Table 2. Thiamin content $(\mathrm{mg} / \mathrm{kg})$ of the experimental diets given to turbot (Scophthalmus maximus)

$\begin{array}{cr}\text { Diet no.* } & \text { Total thiamin } \\ \text { I } & 0.19 \\ 2 & 0.62 \\ 3 & 1.12 \\ 4 & 2.60 \\ 5 & 5.10 \\ 6 & 10.60 \\ 7 & 50.00 \\ 8 \dagger & 0.19\end{array}$

* The basal diet (diet 1 ; for details, see Table $I$ ) was supplemented with graded amounts of thiamin. + Pyrithiamin $(40 \mathrm{mg} / \mathrm{kg}$ ) only was added to the basal diet.

added to the tank. These were again eaten quickly and the procedure was continued, decreasing the number of pellets added each time. When the fish stopped feeding, any uneaten pellets were siphoned from the tank and dried to constant weight. From this weight and that of the pellets originally weighed but not offered to the fish, the total weight of food eaten daily was calculated.

The fish were weighed, using the procedure described by Cowey, Adron, Blair \& Shanks (1974), every 2 weeks throughout the I6-week experiment. The fish tanks were housed in a constant-temperature room with a recirculated sea-water system incorporating a biological filter. Water and air temperatures were $18^{\circ}$.

At the end of the experiment six fish were selected at random from each treatment and were killed by a sharp blow on the head. Blood samples were taken from the caudal vein and haemolysates were prepared as described by Brin, Tai, Ostashever \& Kalinsky (1960). Erythrocyte transketolase (sedoheptulose-7-phosphate: D-glyceraldehyde-3-phosphate glycolaldehydetransferase; $E C \quad 2.2 .1 .1$ ) activity and the 
percentage stimulation of erythrocyte transketolase by pre-incubation of the haemolysate with thiamin pyrophosphate (TPP) (TPP stimulation \%) were then measured using the methods of Brin et al. (I960), except that incubations were carried out at $30^{\circ}$. All the transketolase measurements were made on the same day and were based on pentose utilization. Preliminary measurements of erythrocyte transketolase activity in wild turbot showed good agreement between values based on pentose utilization and those based on hexose formation. As pentose utilization was considerably greater than hexose formation in these preliminary experiments the former measurement was used routinely to estimate erythrocyte transketolase activity in the turbot given diets containing graded levels of thiamin. Six fish/treatment was the maximum number that could be assayed in $\mathrm{I} d$.

\section{RESULTS}

Mean body-weights of the groups of turbot given the different diets and weighed at intervals of $14 \mathrm{~d}$ are shown in Table 3 . Good growth occurred with diets $\mathrm{I}-7$ until about the I 2 th week of the experiment, when turbot given diet I ceased to gain weight. Turbot given diets 2-7 continued to gain weight at about the same rate until the end of the experiment. An analysis of variance between treatments showed that there were no significant differences in weight gain between treatments up to the rath week of the experiment. Between weeks 12 and $14(P<0.01)$ and between weeks 14 and 16 $(P<0.001)$ however, there were significant differences in weight gain between treatments.

To determine for which treatments the weight gains were significantly different the values for weight gain for the final 4 weeks were further analysed by Student's $t$ test. This analysis showed that the turbot given diet $\mathrm{I}$ gained significantly less weight $(P<0.02$ for weeks 13 and $14 ; P<0.0$ for weeks 15 and 16$)$ than the turbot given any other diet.

No outward signs of thiamin deficiency were observed in any of the turbot. Also there were no mortalities that could be attributed to thiamin deficiency among any of the turbot given diets I-7. Two fish were lost, one from each of dietary treatments 2 and 7 , during the IIth week of the experiment. These fish escaped from their tanks and died of asphyxiation. These individuals were eliminated from the analysis of weight gains.

Food consumption by the turbot is shown in Table 4. The food was eaten well, suggesting that it was acceptable to the turbot, and food consumption for the seven groups was similar during the first 12 weeks of the experiment. For the final 4 weeks of the experiment there appeared to be a progressive decrease in food consumption by turbot given diet I, suggesting some loss of appetite by this group at this time.

Turbot given diet 8 containing pyrithiamin grew normally during the first 6 weeks but by the end of the 8th week appeared to be gaining weight less rapidly than the fish given diets $1-7$. Two of the fish given diet 8 died during the 8 th week of the experiment without displaying any serious deficiency signs. Because of an absence of deficiency signs, no attempt was made to administer thiamin to the turbot given diet 8 and the remainder of them died between the 8 th and roth weeks. 
Vol. 34

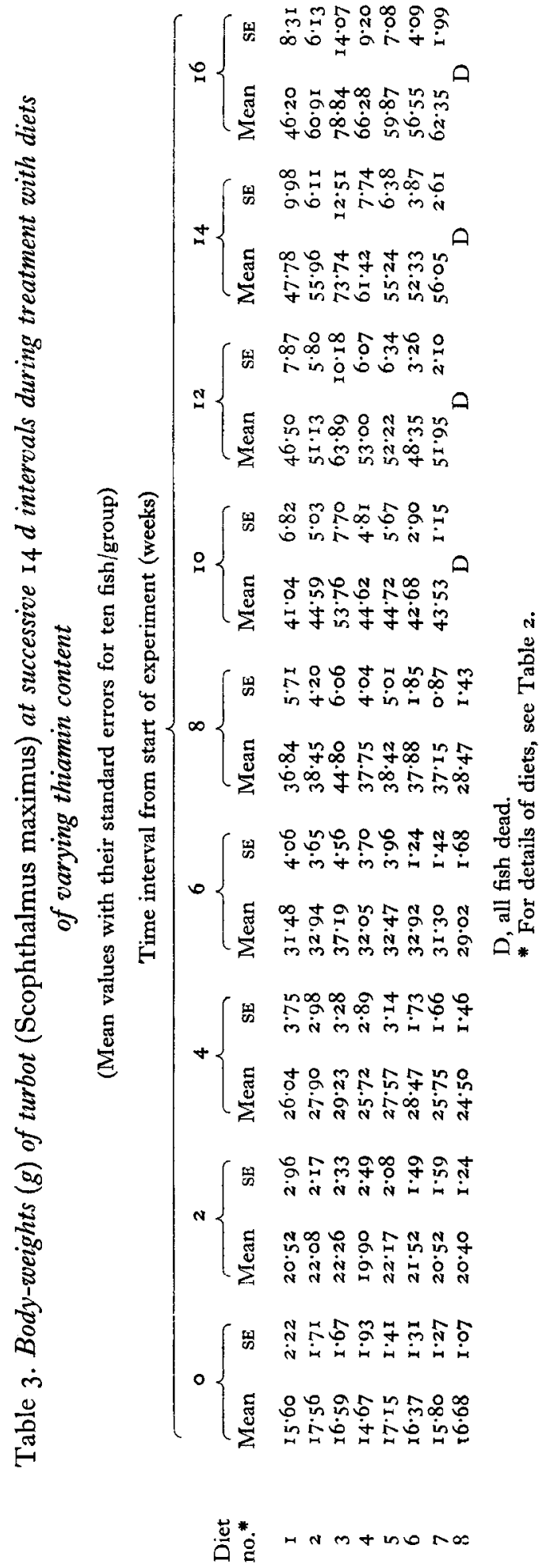


Table 4. Mean food consumption ( $\mathrm{g} / \mathrm{kg}$ biomass per $\mathrm{d}$ ) of groups of turbot (Scophthalmus maximus) during a r6-week experiment with diets of varying thiamin content

\begin{tabular}{cccc} 
& \multicolumn{3}{c}{ Food consumption } \\
Diet no.* & Weeks I-12 & Weeks I3 and I4 & Weeks I5 and I6 \\
I & I3.7 & 12.0 & 9.1 \\
2 & II .5 & 13.6 & 13.5 \\
3 & 12.2 & 12.7 & 12.0 \\
4 & 12.5 & 15.4 & 14.5 \\
5 & 12.3 & 14.4 & 13.8 \\
6 & 13.0 & 14.0 & 13.9 \\
7 & 14.6 & 13.8 & 13.0 \\
& $*$ For details of diets, see Table 2.
\end{tabular}

Table 5. Effect of dietary thiamin level on turbot (Scophthalmus maximus) erythrocyte transketolase (sedoheptulose-7-phosphate: D-glyceraldehyde-3-phosphate glycolaldehydetransferase; EC 2.2.I. I) activity and on percentage stimulation of erythrocyte transketolase activity by thiamin pyrophosphate (TPP stimulation \%) in blood samples taken after 16 weeks of treatment

(Mean values with their standard errors for six fish/group)

\begin{tabular}{|c|c|c|c|c|}
\hline \multirow[b]{2}{*}{ Diet no.t } & \multicolumn{2}{|c|}{$\begin{array}{c}\text { Transketolase activity } \\
\text { (mg substrate transformed } / \mathrm{h} \\
\text { per ml haemolysate) }\end{array}$} & \multicolumn{2}{|c|}{ TPP stimulation $\%$} \\
\hline & Mean & SE & Mean & SE \\
\hline $\mathbf{I}$ & 0.42 & 0.09 & $47 \cdot 74$ & $4 \cdot 48$ \\
\hline 2 & 0.45 & 0.13 & $44 \cdot 36$ & $7 \cdot 18$ \\
\hline 3 & 0.43 & 0.16 & $4 I \cdot 02$ & $8 \cdot 5^{8}$ \\
\hline 4 & 0.65 & 0.14 & $8 \cdot 65$ & 3.70 \\
\hline 5 & 0.59 & 0.19 & $4 \cdot 28$ & $I \cdot 64$ \\
\hline 6 & 0.57 & 0.11 & $9 \cdot 28$ & $3 \cdot 8 \mathrm{I}$ \\
\hline 7 & 0.57 & 0.13 & $I \cdot 92$ & $\mathrm{I} \cdot 24$ \\
\hline
\end{tabular}

* Percentage stimulation of erythrocyte transketolase activity by pre-incubation of a haemolysate with thiamin pyrophosphate; for details, see p. 368 .

$\uparrow$ For details of diets, see Table 2.

Erythrocyte transketolase activities (Table 5) were highest in turbot given diets 4-7. Appreciable stimulation of transketolase activity by pre-incubation of haemolysates with TPP occurred only in samples taken from turbot given diets I-3. It is noteworthy that pre-incubation of these haemolysates with TPP restored transketolase activity to levels present in turbot given diets $4-7$. It may therefore be inferred that apoenzyme levels in turbot from diets $\mathrm{r}-3$ were normal and that coenzyme levels were deficient.

Blood was taken from three of the fish given diet 8 but, as there was an unavoidable delay in assaying the transketolase activity in these samples, the low values obtained were discounted. 


\section{DISCUSSION}

The present experiments indicate that the thiamin requirement of turbot is much lower than that reported for certain freshwater fish (Halver, 1972) but is of a similar order to that reported for carp (Aoe et al. 1969). Turbot given a diet containing $0.19 \mathrm{mg}$ thiamin $/ \mathrm{kg}$ ceased to gain weight after 12 weeks, but at the next highest dietary thiamin level used $(0.62 \mathrm{mg} / \mathrm{kg}$ ) weight gain continued normally for up to $\mathrm{I} 6$ weeks when the experiment had to be terminated.

The seven thiamin levels used in the experiment were selected on the basis of the stated requirements of certain freshwater fish in the expectation that they would lead to a typical dose-response curve. In the event and because the thiamin requirement of turbot is evidently much lower than that of these freshwater fish several of the selected dietary thiamin levels proved superfluous, being well in excess of the requirement of the turbot, and a meaningful dose-response curve was not obtained.

It may appear that such a dose-response curve might readily have been obtained by using much lower dietary levels of thiamin. Unfortunately this proved extremely difficult in practice because when materials free of thiamin (e.g. vitamin-free casein) were used to supply all the protein in the diet then the diets became unpalatable to the turbot and very low growth rates were obtained (cf. Hashimoto et al. 1970). Other approaches such as solvent extraction (hot aqueous ethanol) or thiaminase treatment of materials commonly used in flatfish diets (e.g. fish meal) also rendered these materials unpalatable to the fish.

It is also noteworthy that a characteristic of the diets used to evaluate thiamin requirements of omnivorous birds and mammals has been the high content of carbohydrate, up to $900 \mathrm{~g} / \mathrm{kg}$ (Koedam, 1958). By contrast marine flatfish require high dietary levels of protein for growth (Cowey et al. 1972) and the scope for using diets with very high carbohydrate contents in experiments with these animals is limited, especially if good growth rates are desired. Moreover, carbohydrate is metabolized slowly by marine flatfish, probably because glucose is only slowly phosphorylated in the liver (Cowey, Brown, Adron \& Shanks, I975).

Erythrocyte transketolase activity, and especially TPP stimulation \%, has been shown recently to be a useful, sensitive and specific method for the study of thiamin status in pigs (Peng \& Heitman, 1973) and previously had been shown to be similarly useful in rats and humans (Brin et al. 1960; Brin, 1962) pigeons (Lofland, Goodman, Clarkson \& Prichard, 1963) and the duck (Brin, 1964). In the absence of diagnostic signs of thiamin deficiency in the turbot at the dietary levels used it was not possible to evaluate erythrocyte transketolase activity as a criterion of thiamin status in turbot. Nevertheless the measurements of erythrocyte transketolase activity and TPP stimulation $\%$ which were made show that in turbot given, for 16 weeks, $2.6 \mathrm{mg}$ thiamin $/ \mathrm{kg}$ diet all the erythrocyte transketolase is fully saturated with coenzyme (TPP). Taken together with the growth data these findings strongly suggest that the dietary requirement of turbot for thiamin is very much less than that reported for trout, salmon and channel catfish ((US) National Research Council, 1973) and is between 0.62 and $2 \cdot 60 \mathrm{mg} / \mathrm{kg}$ dry diet. 
The reason for the apparent disparity in dietary thiamin requirement of different species of fish is obscure. One factor which may affect the issue is the level of thiaminase activity and its location in the gut, and possibly other tissues, of these fish. Available information does not allow any simple explanation; thus the carp, which contains thiaminase in its tissues, has a low dietary thiamin requirement while rainbow trout (Salmo gairdnerii) and Chinook salmon, which are said to lack thiaminase in their body (Harris, I951; Hashimoto et al. 1970), require much more dietary thiamin. The resolution of this apparent paradox will probably await precise examination of the connexion between tissue thiaminase distribution and dietary thiamin requirement.

Experiments with mice (Euselsi \& Cerecedo, 1950) and with pigeons (Koedam, 1958) have shown that pyrithiamin is a potent antagonist of thiamin and probably acts by inhibiting the phosphorylation of thiamin to TPP. The results of Koedam's (1958) experiments suggest that there is a close resemblance between thiamin deficiency induced by giving pyrithiamin together with thiamin, and that induced by giving diets free of thiamin. Reid, Hove, Braucher \& Mickelsen (1963) also observed thiamin-deficiency signs in the rabbit when this antagonist was used. Thus the most reasonable interpretation of our results with this antagonist (diet 8 ) is that it induced a thiamin deficiency in the fish resulting in death.

No deficiency signs were observed in the turbot given the diet containing pyrithiamin. In this connexion it must be borne in mind that signs typical of thiamin deficiency in free-swimming fish, for example loss of equilibrium, instability in the water, and in eels flexion of the trunk, would be much less obvious, if they occur at all, in a bottom-living fish which spends much of its time motionless on the bottom of the tank.

\section{REFERENCES}

Aoe, H., Masuda, I., Mimura, T., Saito, T., Komo, A. \& Kitamura, S. (1969). Bull. fap. Soc. scient. Fish, 35, 459 .

Brin, M. (1962). F. Nutr. 78, 179.

Brin, M. (1964). Fedn Proc. Fedn Am. Socs exp. Biol. 23, 242.

Brin, M., Tai, M., Ostashever, A. S. \& Kalinsky, H. (1960). F. Nutr. 7r, 273.

Cowey, C. B., Adron, J. W., Blair, A. \& Shanks, A. M. (1974). Br. F. Nutr. 31, 297.

Cowey, C. B., Brown, D. A., Adron, J. W. \& Shanks, A. M. (1975). Br. F. Nutr. 33, 219.

Cowey, C. B., Pope, J. A., Adron, J. W. \& Blair, A. (r972). Br. F. Nutr. 28, 447.

Euselsi, A. J. \& Cerecedo, L. R. (1950). Fedn Proc. Fedn Am. Socs exp. Biol. 9, I69.

Halver, J. E. (editor) (1972). In Fish Nutrition, p. 29. New York: Academic Press.

Harris, R. J. (I95I). In The Enzymes, rst ed., vol. I, p. I I86 [J. B. Sumner and K. Myrbäck, editors]. New York: Academic Press.

Hashimoto, Y., Arai, S. \& Nose, T. (1970). Bull. Ұap. Soc. scient. Fish. 36, 791.

Jones, A. (1973). Aquaculture 2, 149.

Koedam, J. C. (1958). Biochim. biophys. Acta 29, 333.

Lofland, H. B. Jr, Goodman, H. O., Clarkson, T. B. \& Prichard, R. W. (1963). F. Nutr. $79,188$.

National Research Council (1 973). Nutrient Requirements of Domestic Animals No. I I, Nutrient Requirements of Trout, Salmon and Catfish. Washington, DC: National Research Council.

Peng, C.-L. \& Heitman, H. Jr (r973). Br. F. Nutr. 3o, 391.

Reid, J. M., Hove, E. L., Braucher, P. F. \& Mickelsen, O. (1963). F. Nutr. 8o, $3^{81}$.

Sarett, H. P. \& Cheldelin, D. H. (1944). F. biol. Chem. x55, I53. 